\title{
Socio-psychological Training for Readiness for Interaction in Professional Activity of Employers and Specialists with Blindness
}

\author{
Yevhenii Klopota $^{1}$, Olha Klopota ${ }^{2}$, Vytautas Gudonis ${ }^{3}$
}

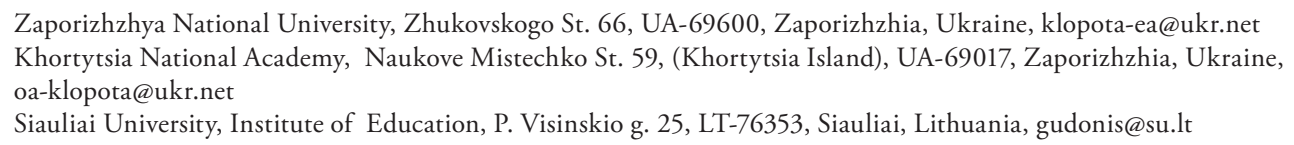

Siauliai University, Institute of Education, P. Visinskio g. 25, LT-76353, Siauliai, Lithuania, gudonis@su.lt

\begin{abstract}
The article contains the results of an experimental analysis of the peculiarities and prospects of the interaction of specialists with blindness with their potential employers. Young people with blindness and chiefs of different organizations and institutions (potential employers) took part in the experimental analysis of the readiness for interaction in professional activities. We have received positive dynamics in influencing the emotional component of self-identity of people with profound visual impairment; tendency on a behavior, focused on solving the problem; increasing the level of self-control and independence of other people's estimation. On the other hand, the most of potential employers have proven themselves in full capability of people with visual impairment, who can provide a productive professional career.
\end{abstract}

Keywords: professional competence, integration, readiness for interaction, specialists with visual impairment or blindness, employers.

\section{Introduction}

The choice of profession is paramount importance in life and formation of the identity of young people. Often, people with profound visual impairment overestimate their strength and visual capabilities and choose the profession that can further deteriorate their state of view. Different types of professional activities also impose different requirements. Therefore, it is very important to determine the scope of their future activities in a timely 
manner. An active life position of the young people is formed in the process of education and upbringing, and depends directly on current social experience. The following tasks are solved: the development of a conscious attitude towards learning, social formation, intellectual and physical development of the individual, development and formation of social value, attitude to work, formation of the bases of socially significant needs for active participation in socially useful work, acquaintance with professions in the process of professional activity realization. The participation of students in professional activities is the basis of their preparation for life and work in modern society.

It should be noted that formation of professional competence and personality as a professional is closely connected with the self-determination of the individual, his selfrealization, self-affirmation, self-perfection, self-knowledge. This process is conditioned by the manifestations of internal resources, efforts, and attitudes towards the professional development of a person. In addition, self-realization of a person as a professional, means an identification, a self-awareness as part of a professional sphere, which includes not only the social environment (colleagues, subordinates and leaders), but also the object of labor, on which person's professional activity is directed.

On the other hand, professional environment and potential employers are not ready for understanding and interacting with people who have a profound visual impairment. Therefore, it is very important to optimize interaction and to increase readiness for cooperation of potential employers and specialists with blindness.

Integration and labor are the most important stages in the process of youth socialization. In particular, it concerns young people with visual impairments. At the integration stage, a personality has a desire to find his place in society. The success of the integration process depends on the person's perception by other members of social groups. At the labor stage person not only assimilates the social experience, but affects the environment by means of professional activities. Today's conditions require competitive professionals, which not only acquire capabilities to operate with the knowledge, but are also able to adjust to the needs of the labor market.

\section{Research Focus}

The analysis of scientific literature (Gudonis, Klopota, 2017), (Ermakov, Seliverstova, 2002), (Klopota, Klopota, 2017), (Kobylchenko, 2016), (Tyushev, 2008), (McDonnall, O'Mally, Crudden 2014) suggests that the concept of 'competence' reflects a certain level of the person's professionalism. The term 'professional' we understand as a special property of human who efficiently, systematically, reliably performs complex actions in the most diverse conditions.

The development of personality contributes to the self-representation as a professional. (Viršulienė, 2016), (Baraniewicz, Gołąbek Jonak, 2018) (Golubeva, Guntersdorfer, 2017). 
Development of a strategy of approaching the reference model and the aspiration to it determine one of the ways of personal improvement. At the same time, full or partial blindness affects the status of a person in the field of social production.

This concept shows the degree of mastery of the human structure of professional activities that meets the current standards in society and objective requirements.

There are four stages of professionalization: search and career choices; development of the profession; social and professional adaptation; performance of professional activities.

Acquisition of professionalism requires adequate knowledge, skills, as well as desire and willingness to learn. In this case, professionalism includes not only the presence of high qualification, but also an adequate worldview of a person as an essential component of his professional competence. As professional competence we understand an integral characteristic, which determines a person's ability to solve both typical professional problems and problems arising in real situations of professional activity through the use of acquired knowledge and skills, acquired professional and personal experience, values and inclinations.

Different types of professional activities put forward different requirements for the visual analyzer; therefore, the professional orientation of people with visual impairment or blindness should be based on their visual capabilities and the specificities of the chosen profession.

Professional and socio-psychological aspects of labor adjustment, consisting of physiological, personal-psychological, behavioral and social components can be distinguished.

There are various aspects of adaptation to the profession, consisting of physiological, person-psychological, behavioral and social components. At the same time, the sociopsychological aspect plays a major role in the process of adaptation and integration of people with visual impairment or blindness into society.

The optimization of socialization and integration processes of those people who have visual impairments is one of the main tasks, which are set by educational systems in the world. The formation of personal potential occurs through activity, which becomes a professional sphere in the future. The core of the integration process of the individual is labor as a tool of social security and success in public life.

In modern social, pedagogical and psychological literature much attention is paid to the problem of readiness for professional self-determination and interaction of young people. They can distinguish the following levels of readiness of the individual to professional self-determination: psychophysical, moral and practical readiness.

In our opinion, the formation of person's readiness for self-determination is one of important ways of modern education. First of all, it is possible under a condition of psychical patterns of becoming individual and self-determination.

In addition, psychological readiness should be considered as a personal quality, which determines the settings for professional orientation and solving the problems of 
self-determination, active status of the individual, contributing to the focus, sustainability and effectiveness of further activities.

The willingness to form a professional competence is a structured entity that provides the necessary internal motives for the successful performance of professional functions and professional growth. This readiness is not an inborn phenomenon, but acquires its own development as a result of life experience and human learning.

Therefore, some researchers (Gudonis, 2017), indicate that the major obstacle towards the integration of people with visual impairments is a low level of specialized technical facilities during the professional training and a program of vocational guidance for working with such youth, which is not designed enough. At the same time, there should be noted that there are difficulties in future careers, faced by children with blindness who are graduates of schools. In particular, there are difficulties of interpersonal communication, a gap between intellectual development and ability to realize their potentialities, insufficient schooling of graduates for independent professional and social life.

According to the results of our research, there are less than one percent of students with visual impairment or blindness after graduation in Ukraine who works in the field of their specialty.

There are 4 basic barriers, which hinder relationships between such people and employers:

1. The stereotype of perceiving such people as personalities that differ from others.

2. The fear and non-acceptance of the difference, the lack of knowledge about ways of communicating with them.

3. An acceptance of disabled people as non-effective collaborators, a conviction that their employment will cause unavoidable additional expenses.

4. Insufficient knowledge about legislative acts, concerning the sphere of employment for such people (Wolffe, 2009).

So, it should be noted that youth with visual impairment or blindness after graduation faces significant problems for the further employment. We consider that it is necessary to implement social and psychological support, which is set to help such people.

In particular, it should provide next things: pointing out the peculiarities of professions and required personal qualities, developing the skills of writing personal profile, putting out advertisements to mass media, practicing the technique of making phone calls to the employer, specifics of behavior and self-presentation at the first meeting, appropriate ways of distressing in case of employer's refusal. It causes the necessity of improving socio-psychological ways of creation the positive image for young people with visual impairment or blindness in the society. 


\section{General Background of Research}

An object of our research is the readiness for professional interaction of employers and specialists' with blindness.

The aim of the research is studying of readiness for interaction in the professional activity of employers and specialists with blindness.

Tasks of the research:

1. The analysis of the peculiarities of readiness of employers and specialists with blindness for interaction in professional activities.

2. The revealing of barriers of employers and specialists with blindness interaction in the professional activity.

3. The elaboration and implementation of socio-psychological measures aimed at training of employers and specialists with blindness for interaction in the professional activity.

\section{Research Sample}

We carried out an experimental research in Zaporizhia. This research consisted of the ascertaining, forming and control stages.

The experimental sample consisted of 2 parts: a sample of specialists with blindness and a sample of potential employers. There were 16 people with blindness aged 20-35 (8 women and 8 men) and 32 chiefs of different organizations and institutions (potential employers) who took part in this experimental research. The potential employers were randomly divided into 2 groups: control (group A) and experimental (group B).

\section{Instruments and Procedures}

The present research of some personal components which comply readiness for understanding and communication between potential employers and those with deep visual impairment, has demanded to apply the following psycho-diagnostic methods: 'Identifying the views of potential employers on the professional capabilities of specialists with blindness' (elaborated by us), 'Diagnosis of emotional intelligence' N. Holl (Fetiskin, Kozlov, Manuilov, 2005), 'Personal differential' (Fetiskin, Kozlov, Manuilov, 2005), 'Coping behavior in stressful situations' S. Norman, D. Endper, D. James, M. Parker (Fetiskin, Kozlov, Manuilov, 2005).

With the purpose of verifying and confirming of credibility the obtained results, a mathematical and statistical analysis was applied using Mann-Whitney U Test.

The quantitative analysis was carried out using the computer program 'Statistica 6.1'. 
The research has followed the tenets of the 'World Medical Association Declaration of Helsinki: Ethical Principles for Medical Research Involving Human Subjects'.

We had informed consent from the participants.

\section{Research Results}

At the ascertaining stage, each group was suggested to hire a person with blindness, whose profession confirms the company's profile. Herewith only $6,25 \%$ of chiefs of organizations from each group agreed to consider our proposal. All the other chiefs of organizations refused unappeasable. In addition, a survey aimed at finding out the organizations chiefs' views about the abilities of specialists with blindness which were shown there.

At the forming stage we have suggested the organizations' chiefs, which were selected into the experimental group, to take part in our research. During the experimental work the following arrangements were organized:

1. Video clips about success of the people with blindness in different life spheres were demonstrated to the chiefs of organizations (employers) in the experimental group;

2. Printed materials about individual features of people with visual impairments were given there; also there was information about the ways of breaking the informational, architectural and other barriers by such people, which appeared because of these visual impairments.

3. Conversations on the topic: 'Specialists with blindness in a professional team', which includes analysis of interpersonal interaction between a person with blindness and other specialists of this organization.

4. At the end of the specified events we proposed to the chiefs of organizations, who are the members of the experimental group, to take one specialist with blindness to their institution for a two-week free traineeship.

All proposed events were aimed at creating a positive image of an employee with blindness in the mind of the employer.

In addition, the forming stage of our psychological experiment assumed the implementation of events aimed at 16 specialists with blindness. Based on the fact, that one of the main directions of socio-psychological support is the psychological personal training for people with a visual impairment to the successful society's life, we developed and actualized such events:

1. Conversation on the topic: 'My interactions in a professional team' in which the stereotypes and attitudes to the person with blindness in society were analysed.

2. Individual consultations which relate to problems that are bound up with future professional activities, specifically: emotional, social-psychological and technical workstation adaptation. 
3. Socio-psychological training, the purpose of which was developing the ability to self-determination of the life goals, self-direction for the future, increasing the effectiveness of interpersonal communication, determining the area of the professional activity of people with visual impairment. We offered an intensive form of a socio-psychological training course designed for 15 hours during 3 days. 16 people with blindness were divided into 2 groups according to the developed fundamentals of training work with such people.

We tracked such general training processes: deepening awareness of emotional states and feelings; formation of a sense of belonging to a group; self-disclosure; approbation of new patterns of behavior; feedback from the group.

Process of self-perception of the group's members took place in such directions:

1. The perception of their inner self through comparison with others that is to say using the image of the 'another' as a model which is suitable for introspection and a view from the side which makes it possible to identify and compare yourself with the other members of the group.

2. The self-perception through perception by other, that is to say using of information transmitted by surrounding people based on feedbacks. This allows participants to get others' opinion about yourself through their statements, feelings, behavior.

3. The self-perception through activities results, that is to say an assessment of what the person did. This way of self-esteem strengthens the notion about your own capabilities.

4. The self-perception through observation of eigenstates which gives an understanding of your inner world.

5. The self-perception through assessment of their own appearance. While accepting themselves, one develops his or her own potential abilities.

For discovering the effectiveness of the held socio-psychological training on the established and control stages of research we had held following methods: 'Diagnosis of emotional intelligence' (Fetiskin, Kozlov, Manuilov, 2005), 'Personal differential' (Fetiskin, Kozlov, Manuilov, 2005), 'Coping behavior in stressful situations' (Fetiskin, Kozlov, Manuilov, 2005).

In order to discover the ability to understand the attitude of a person with visual impairment that is represented by emotions and to manage the emotional sphere on the basis of making decisions, we have held the methodics 'Diagnosis of emotional intelligence' (Fetiskin, Kozlov, Manuilov, 2005). Thus, we can mention that on the control stage of the experimental research the average level (54,5\%) of emotionally informed examines people with blindness increased (table 1). 
Table 1

Comparative characteristics of the levels of emotional intelligence of people with blindness at different stages of the study (in \%)

\begin{tabular}{lccc}
\hline \multicolumn{1}{c}{ SCALE } & Levels & Ascertaining Stage & Control Stage \\
\hline Emotional awareness & low & 41.3 & 32.4 \\
& average & 37.1 & 54.5 \\
& high & 21.6 & 23.1 \\
\hline Manage your own emotions & low & 49.5 & 29.7 \\
& average & 16.3 & 48.2 \\
& high & & 22.1 \\
\hline Self-motivation & low & 53.1 & 24.3 \\
& average & 35.7 & 43.6 \\
& high & 11.2 & 32.1 \\
\hline Empathy & low & 45.4 & 31.5 \\
& average & 34.3 & 42.4 \\
& high & 20.3 & 26.1 \\
\hline Recognizing the emotions of & low & 50.1 & 28.3 \\
other people & average & 34.3 & 46.2 \\
& high & 15.6 & 25.5 \\
\hline \multirow{2}{*}{ Integrative level } & low & 46.5 & 19.3 \\
& average & 42.3 & 57.1 \\
\hline
\end{tabular}

It means that people with visual impairment or blindness started to pay more attention to the emotional state of other people and think more about their significance in interpersonal interaction. In addition, the average and high levels of managing of their own emotions on the control stage of the study have been increased. It must be noted, that after the individual consultations, socio-psychological training significantly increased the average and high level of self-motivation. Motivation is important for a successful integration in society of people with visual impairment.

On the control stage of the experimental research, the level of empathy and understanding of other people's emotions in person with visual impairment or blindness has increased. It means, that from childhood a person with blindness has quite serious problems in recognizing emotional states of others, but psychological measures can improve this sphere of interaction.

Finally, according to integrative measure of emotional intelligence essential distinctions mathematical-and-statistical analysis upon the Mann-Whitney U Test $(\mathrm{P}<0.02)$ testify that we have received a positive dynamics in influencing emotional component self-identity with profound visual impairment.

Using 'Personal differential' (Fetiskin, Kozlov, Manuilov, 2005), we examined changing of the people's attitude with blindness to themselves and another people on the control stage of experimental investigation. 
The developed methodology version includes poles of three classic factors of semantic differences: valuing, strength and activity. In the control stage of experimental investigation the average $(49,5 \%)$ and high levels $(34,1 \%)$ among people with blindness according to factor (0) considerably increased (table 2).

Table 2.

Comparative characteristics of the levels of personality differential of people with blindness at different stages of the study (in \%)

\begin{tabular}{rccc}
\hline SCALE & Levels & Ascertaining Stage & Control Stage \\
\hline \multirow{3}{*}{ Rating (O) } & low & 41.3 & 16.4 \\
& average & 36.6 & 49.5 \\
& high & 22.1 & 34.1 \\
\hline \multirow{3}{*}{ Power (C) } & low & 46.1 & 18.7 \\
& average & 38.3 & 51.2 \\
& high & 15.6 & 30.1 \\
\multirow{3}{*}{ Activity (A) } & low & 37.3 & 29.1 \\
& average & 45.1 & 52.4 \\
& high & 17.6 & 18.5 \\
\hline
\end{tabular}

It testifies that they began to identify themselves as a personality, and they are inclined to perceive themselves as a bearer of positive, socially desirable characteristics. So, in a certain context, they are content with themselves. It is also confirmed by essential differences of mathematical experimental analysis. We can observe positive dynamics on the control stage of experimental investigation in accordance to factor (C). These essential differences in results of the experimental group on the control stage are validated upon the Mann-Whitney U Test $(\mathrm{P}<0,02)$.

Therefore, socio-psychological training had a positive impact on the development of volitional qualities of personality in other words how they are realized as a person.

It should be noted that the level of self-control, independence from other people's assessments increased among people with blindness. At the same time, there were no significant changes by the factor (A). In our opinion, it may possibly be explained by the fact that the level of extraversion of the individual cannot be significantly improved in the short term.

To identify the dominant coping strategies of the person with impaired vision, we have used the method of 'Coping behavior in stressful situations' (Fetiskin, Kozlov, Manuilov, 2005). The respondents were offered a list of specific reactions to stressful situations (table 3). 
Table 3.

Comparative characteristics of the coping-behavior in stressful situations of people with blindness at different stages of the study (in \%)

\begin{tabular}{lcc}
\hline Orientation of coping-behavior & Ascertaining Stage & Control Stage \\
\hline Solution of the problem & 28.5 & 52.9 \\
\hline Emotions & 49.4 & 55.3 \\
\hline Escape & 61.8 & 39.5 \\
\hline
\end{tabular}

Therefore, it is possible to highlight three main coping strategies:

- $\quad$ solution of the problem-oriented strategy (active behavioral one to solve problems that arise);

- $\quad$ solution of the emotion-oriented strategy (seeking help and support to the social environment that surrounds the person);

- $\quad$ solution of the escape-oriented strategy (a person tries to avoid contact with the environment, that is nothing else but an escape from reality).

In the control stage of the experimental study, respondents with blindness demonstrated positive tendency on a scale coping focused on solving the problem. This shows that they are willing to behave actively in various stressful situations, one of which is joining the collective of sighted people.

At the same time, on the coping scale focused on emotions, there weren't any significant changes. In our opinion, this indicates sufficiently emotional experiences of such people, possible level of sensitivity to the insults of the other, anxiety, fear, aggression.

On a scale of escape-oriented strategy in the control stage of an experimental study, it is possible to follow positive dynamics of readiness for interaction with sighted people and of solving problematic situations that arise in various spheres of life.

The both samples: a sample of specialists with blindness and a sample of potential employers took part in control stage of the experimental research (after the socio-psychological training).

We offered the control and experimental groups of chiefs of organizations (potential employers) to hire specialist with blindness and conducted a questionnaire which purpose was to find out: whether the director's attitude to the blind specialist changed.

The analysis of the results of control measurements in the control group of potential employers has shown the following: if on the ascertaining stage, 6,25\% of potential employers were ready to consider possibility of hiring a professional with blindness, on the control stage they all refused to employ that person. Such behavior, as it is explained by the directors (potential employers), was caused by the initial reluctance to employ a specialist with blindness. That means that they initially politely tried to refuse. Besides, only $12,5 \%$ of potential employers in the control group think that people with blindness can have a full-fledged work. 
On the other hand, in contrast to the control group, the results of the members of the experimental group have significant differences; in comparison with ascertaining stage in the experimental group, we can state the following conclusions. So, the analysis of information on the control stage of our research proved that:

- $25 \%$ of potential employers (chiefs of organizations) are members of the experimental group who offered experts with blindness to stay in their companies in order to continue their job;

- $18,75 \%$ potential employers are members of the experimental group who offered to have some additional internship for experts with blindness with the future discussion of a possibility to get a job for them;

- $62,5 \%$ of potential employers (chiefs of organizations) have proven themselves in full potential of people with visual impairment, who can provide a productive professional career.

\section{Conclusions}

The results of the experimental analysis of peculiarities and prospects of readiness for interaction in the professional activity of specialists with blindness with potential employers are presented in the article. It is proved that socio-psychological aspects play a leading role in the process of professional integration and self-realization of people with visual impairment in the society.

Based on the obtained results, we can conclude that the success of the interaction in the professional environment depends on readiness for understanding and communication between potential employers and those with deep visual impairment. In other words, solving the problem of optimizing the conditions for integration into society and the professional self-realization of people with blindness is possible through the development and implementation of socio-psychological support measures, among the most important directions of which are the following:

1. Professional information and giving recommendations to young people with blindness (with taking into account their psychological and psychophysical features, as well as the needs of modern society and the free labor market) in a process of self-determination and making informed decisions about choosing a job.

2. Elaboration and implementation of socio-psychological measures aimed at training of employers and specialists with blindness for interaction in the professional activity.

3. Identify and overcome the barriers of interaction between employers and professionals with blindness in professional activities; increasing the knowledge of employers regarding the specific needs and potential of specialists with blindness.

4. Providing conditions for adapting a working place of a person with blindness based on the innovative modern technologies, conducting individual consulting. 
The proposed results confirm the benefits and importance of developed and implemented socio-psychological measures aimed at increasing the willingness for cooperation of specialists with blindness and their potential employers.

Summing up, socio-psychological support for integration in the professional circle of people with blindness should be aimed at increasing the effectiveness of the professional interaction of employers and specialists with visual impairment or blindness.

\section{References}

Baraniewicz D. \& Gołąbek Jonak P. (2018). Combining Theory and Practice in the Professional Preparation of Future Special Educators - the Perspective of Students. Pedagogika, 129(1), 33-52. Prieiga per internetą: http://www.pedagogika.leu.lt/index.php/Pedagogika/article/ view/824/366

Ermakov, V. \& Seliverstova, V. (2002). Professional Orientation of Pupils with Visual Impairment: Medicine, psychology, pedagogy. Moscow, Humanity. ed. Center Vlados.

Fetiskin, N., Kozlov, V., \& Manuilov, G. (2005). Social-psychological Diagnosis of Personality Development and Small Groups. Moscow, Publishing House of the Institute of Psychotherapy.

Golubeva I. \& Guntersdorfer I. R. (2017). Preparing Professionals for Working in Multicultural and Democratic Europe: Two Pedagogical Programs - Their Assessment and Collaborations. Pedagogika, 128(4), 39-54. Prieiga per internetą: http://www.pedagogika.leu.lt/index.php/ Pedagogika/article/view/746/345

Gudonis, V. \& Klopota, Y. (2017). Features of Interpersonal Interaction of Blind and Visually Impaired Youth with Student Group. Pedagogika, 125(1), 132-142. Prieiga per internetą: http:// www.pedagogika.leu.lt/index.php/Pedagogika/issue/view/17/showToc

Klopota, Y. \& Klopota, O. (2017). Peculiarities of Interpersonal Cooperation of Youth With Different Vision Level. New Educational Review, 48(2), 227-238. Prieiga per internetą: http:// www.educationalrev.us.edu.pl/e48/a18.pdf

Kobylchenko, V. (2016). Specific Patterns of Personality Development of the Child with Profound Visual Impairments. Topical issues of pedagogy, psychology and professional education, (1), 85-91. Prieiga per internetą: $h$ ttp://journals.uran.ua/apppfo/article/view/73460/68852

McDonnall, M. C., O'Mally, J., and Crudden, A. (2014). Employer Knowledge of and Attitudes Toward Employees Who Are Blind or Visually Impaired. Journal of Visual Impairment \& Blindness, 108(3), 16-28. Prieiga per internetą: https://www.afb.org/afbpress/newpubjvib. asp?DocID=jvib080305

Tyushev, Yu. (2008). Choice of the Profession: Training for Adolescents. St. Petersburg: Peter.

Viršulienè K. (2016). Developing Student-teacher's Instructional Communication Skills through Teaching Practice: the Attitudes of Mentors. Pedagogika, 121(1), 101-112: Prieiga per internetą: http://www.pedagogika.leu.lt/index.php/Pedagogika/article/view/315/234 
Wolffe, K. (2009). Fertigkeiten für den Erfolg: Berufliche Bildung für Kinder und Jugendliche mit einer Sehschädigung. Kongressbericht «Teilhabe gestalten»Verband der Blinden- und Sehbehinderten-pädagogen und -pädagoginnen e.V. (Hrsg.). Wurzburg: Edition Bentheim, 153-165.

\title{
Socialinis ir psichologinis pasirengimas darbdavių ir neregiu specialistų sąveikai profesinèje veikloje
}

\author{
Jevgenijus Klopota ${ }^{1}$, Olga Klopota ${ }^{2}$, Vytautas Gudonis ${ }^{3}$
}

\footnotetext{
Zaporožès nacionalinis universitetas, Pedagogikos ir ugdymo psichologijos katedra, Žukovskio g. 66, Zaporožè, UA-69017, Ukraina, klopota-ea@ukr.net

2 Khortytskos nacionalinè edukacinè reabilitacijos akademija, Socialinio darbo katedra, Mokslo miestelio g. 59, Zaporožè, UA-69017, Ukraina, oa-klopota@ukr.net

3 Šiaulių universitetas, Edukologijos institutas, P. Višinskio g. 25, 76353 Šiauliai, gudonis@su.lt
}

\section{Santrauka}

Straipsnyje pateikiami neregių specialistų ir potencialių jų darbdavių bendravimo perspektyvos eksperimentinès analizès rezultatai. Gavus visų tyrimo dalyvių (16 jaunų žmonių, turinčių aklumą, ir 32 įvairių organizacijų ir institucijų vadovų, potencialių darbdavių) sutikimus dalyvauti tyrime, pasitelkus psichologinius diagnostinius metodus bei organizavus specialiai parengtus tyrimo dalyvių mokymus, buvo nustatyti pozityvūs poslinkiai. Jauni žmonès, turintys žymių regèjimo sutrikimų ar būdami visiškai akli, geriau gebejjo valdyti savo emocijas, didinti savikontrolę, racionaliau spręsti negalès sukeltas psichologines problemas, adekvačiau vertinti kitus žmones. Dauguma potencialių darbdavių atitinkamai pradejjo vertinti jaunus žmones, turinčius regèjimo negalią, ir įžvelgè jų potencines galimybes ir perspektyvas dalyvauti profesinèje veikloje bei siekti produktyvios profesinės karjeros. Viena vertus, tyrimas atskleidè, kad darbdaviai menkai žino jaunų žmonių, turinčių regèjimo negalią, potencines galimybes, antra, paaiškejjo, kad baigiamųjų klasių moksleiviams, turintiems regos sutrikimų, būtina kompleksinè pagalba rengiant juos profesijai bei profesinei karjerai.

Esminiai žodžiai: profesinè kompetencija, integracija, pasirengimas bendrauti, regos negalia ar akluma turintys specialistai, darbdaviai.

Gauta 20190501 / Received 01052019

Priimta 20190730 / Accepted 30072019 